Uslu, O. (2021). "Does Self-Esteem Really Matter? Determining the Role of Self-esteem in Cynical-Silent Employees", Eskişehir Osmangazi Üniversitesi iiBF Dergisi, 16(3), 615 - 637.

Doi: 10.17153/oguiibf.901024

Başvuru: 22.03.2021 Kabul: 31.05.2021

Araştırma Makalesi/Research Article

\title{
Determining the Role of Self-Esteem in Cynical-Silent Employees
}

\begin{tabular}{|c|c|}
\hline $\begin{array}{l}\text { Benlik Saygısı Gerçekten Önemli midir? Sinik-Sessiz } \\
\text { Çalışanlarda Benlik Saygısının Belirlenmesi }\end{array}$ & $\begin{array}{l}\text { Does Self-Esteem Really Matter? Determining the Role } \\
\text { of Self-Esteem in Cynical-Silent Employees }\end{array}$ \\
\hline \multirow[b]{2}{*}{$\begin{array}{l}\text { Öz } \\
\text { Bu çalışmanın iki amacı bulunmaktadır. İlk olarak, sinizm } \\
\text { ile kabullenici ve savunmacı sessizlik arasında pozitif ve } \\
\text { sinizm ile özgeci sessizlik arasındaki negatif ilişkilerin } \\
\text { olup olmadığını tespit etmek amaçlanmıştır. İkincisi, } \\
\text { davranışsal esneklik teorisine dayanarak tahmin edilen } \\
\text { ilişkilerde benlik saygısının potansiyel düzenleyici etkileri } \\
\text { araştırılmıştır. Nicel bir araştırma tasarlanmış ve } \\
\text { araştırmaya } 522 \text { çalışan dahil edilmiştir. Her ne kadar } \\
\text { benlik saygısının sinik-özgeci sessiz çalışanlar üzerinde } \\
\text { düzenleyicisi etkisi olsa da davranışsal esneklik teorisinin } \\
\text { aksine, kritik bir tampon rolünün olmadığı } \\
\text { gözlemlenmiştir. Bu nedenle mevcut çalışma } \\
\text { bağlamında, benlik saygısının literatürde abartıldığı } \\
\text { ölçüde kayda değer olmadığı sonucuna varılmıştır. }\end{array}$} & Abstract \\
\hline & $\begin{array}{l}\text { The aim of this paper is twofold. First, it was aimed to } \\
\text { determine whether there are positive associations } \\
\text { between cynicism and acquiescent and defensive } \\
\text { silence, and negative association between cynicism and } \\
\text { prosocial silence. Second, drawing on behavioral } \\
\text { plasticity theory, potential moderating effects of self- } \\
\text { esteem in the predicted associations were explored. A } \\
\text { quantitative research was designed, and } 522 \text { employees } \\
\text { included in the research. Even though self-esteem had a } \\
\text { moderating effect on cynical-prosocial silent employees, } \\
\text { and unlike the behavioral plasticity theory it did not have } \\
\text { any critical buffer role. Within the context of current } \\
\text { study, therefore, it has been concluded that self-esteem } \\
\text { is not as significant as it has been exaggerated in the } \\
\text { literature. }\end{array}$ \\
\hline Anahtar Kelimeler: Benlik saygısı, Sinizm, Sessizlik & Keywords: Self-Esteem, Cynicism, Silence \\
\hline JEL Kodları: M12, J20 & JEL Codes: M12, J20 \\
\hline \multicolumn{2}{|l|}{$\begin{array}{l}\text { Araştırma ve } \\
\text { Yayın Etiği } \\
\text { Beyanı }\end{array}$} \\
\hline Çalışmanın tamamı yazar tarafından oluşturulmu & \\
\hline ar açısından ya da üçüncü taraflar açısından ça & ışmadan kaynaklı çıkar çatışması bulunmamaktadır. \\
\hline
\end{tabular}

\footnotetext{
${ }^{1}$ Assist. Prof. Dr., Sakarya University, Sakarya Business School, Business Administration, ouslu@sakarya.edu.tr
} 


\section{Introduction}

Today, the changing business life brings along many innovations in macro and micro scales. These changes are often perceived negatively by the employees and furthermore, they can cause depression, stress, fear of dismissal, insecurity, skepticism, low job satisfaction and conflict in the organizational environment (Cartwirght and Holmes, 2006: 200). Especially the mood disorders experienced by individuals who are resistant to change naturally trigger cynicism and silence behaviors. Research on both cynicism and silence has progressed considerably over the past decades. Previous studies frequently addressed the negative consequences of cynicism and silence attitudes in work settings. Cynicism and silence trigger poor communication, alienation and negative emotionality (Andersson and Bateman, 1997: 455; Bagheri, Zarei and Aeen, 2012: 50) while they create low job satisfaction, low job performance, poor mental health, high burnout, low commitment, low trust and some other critical consequences including higher stress, pessimism, low psychological well-being and depression (Vakola and Bouradas, 2005: 446; Milliken et al., 2003; Mirvis and Kanter, 1989: 381; Chiaburu et al., 2013: 182; Abraham, 2000: 269; Andersson and Bateman, 1997: 449; Bagheri et al., 2012: 50). The negative consequences of cynicism and silence reveal that these attitudes are pivotal in organizational settings. However little research has examined the interaction between these constructs (Zhang et al., 2019; Nikolaou et al., 2011; Mousa et al., 2020; Farjam et al., 2018). On these limited previous research, a call for new research was exist. As well as examining the association between two variables, examining some other constructs that have the potential to affect these variables were also emphasized (Zhang et al., 2019: 250; Çaylak and Altuntaş, 2017: 96). As Andersson and Bateman (1997: 449) states there is a need for a more controlled examination of cynicism and its relation to managerial practices such as silence and its types. Similarly, Morrison and Milliken (2000: 706) asserts that silence literature has not received attention as it has deserved. That is why examining the association between employee cynicism and silence will be useful in response to emphasis of previous research.

The positive association between cynicism and employee silence is strongly supported by theory and research. However, the intention for silence attitude has been mostly ignored or received little attention. The common idea derived from past research is that both cynicism and silence are positively related to each, since they are often considered as negative responses stem from negative emotions and experiences (Nikolaou et al., 2011: 731; Mousa et al., 2020: 3). But employees may prefer to keep silent without encountering any negative condition or experience (Dyne et al., 2003: 1365). They may voluntarily be silent for the benefit of their co-workers and organization. In this context, separately investigating the associations between employee cynicism and different types of silence behavior derived from employees' intentions is pivotal in order to better understand the employee nature in work settings.

Another issue that has been noted in the recent literature is the self-esteem of the employees. As a psychological variable, which has deep and comprehensive effects on emotions and behaviors (Pyszczybski and Kesebir, 2013: 24), self-esteem is thought to affect employees' relationships with other people and their environment (Kernis, 2003: 1). While high self-esteem is assumed to have critical beneficial effects due to positive self-beliefs, low self-esteem is assumed to have detrimental effects (Crocker and Park, 2004: 392). Furthermore, previous studies reflect that self-esteem can be a very strong moderator 
variable (Longmore and Demaris, 1997; Mossholder et al., 1982; Feng and Xu, 2015; Ferris et al., 2010). Although there is a huge literature about the benefits and damages of self-esteem in work settings (Zeigler-Hill, 2013: 50; Stinson et al., 2009: 495; Furnham and Cheng, 2000: 468; Diener and Diener, 2009: 72; Heatherton and Wyland, 2003: 219), the severity of these benefits and damages and whether self-esteem has been exaggerated are still unclear. This issue brings to question to the agenda does really self-esteem matter, especially in workplaces. The purpose of addressing to all those issues has been the driving force to carry out the current study. The aim of this paper is therefore twofold. First, the possible associations between cynicism and acquiescent, defensive, and prosocial as three types of employee silence (Dyne et al., 2003: 1363) were investigated. Second, drawing on behavioral plasticity theory (Brockner, 1988 cited in Ferris et al., 2010: 564), potential moderating effects of self-esteem in the predicted associations of employee cynicism and acquiescent, defensive, and prosocial silence were explored. In addition to above mentioned issues, to the best of author's knowledge, no study investigating the moderating effects of self-esteem in the associations between employee cynicism and different types of silence exists. Hence, current study is expected to contribute to relevant literature. In addition, studies examining the relationship between self-esteem and cynicism as an individual feature and organizational silence are quite limited. The study is also expected to contribute to this gap in the literature. Present study revives an argument, referring to employee psychology. It questions the intention of keeping silent and the background of these intentions by focusing on cynicism and self-esteem. It is expected that the clues revealed by this debate will also contribute to practitioners and researchers.

\section{Definition of Concepts}

In this section, the conceptual framework of the cynicism, self-esteem and organizational silence variables are examined and then the expected relationships between these variables are presented.

\subsection{Cynicism}

Although cynicism is quite common in social environments with its negative consequences, it is frequently neglected in organizations (Dean et al., 1998: 341). However, recently there has been a great increase in academic studies on cynicism. In some of these studies, it is associated with personality traits (Smith et al., 1988), while in others it is described as an emotion (Meyerson, 1990: 296). Andersson and Bateman (1997: 450) defines cynicism as an attitude characterized by negative feelings, mistrust and disappointment towards a person, group, ideology, social contract, or institution. Dean et al. (1998) evaluates the subject in the organizational environment and examines it more specifically. They explain cynicism as an employee attitude consisting of three dimensions towards the organization. These dimensions can be expressed as a belief that the organization lacks honesty, negative feelings towards the organization, and a tendency to exhibit critical behaviors consistent with negative feelings and beliefs (Dean et al., 1998: 345-347). Abraham (2000: 269) mentions five different types of cynicism: personality cynicism, institutional-social cynicism, employee cynicism, organizational cynicism, organizational change cynicism, and business cynicism. Regardless of its type, the common point of most of the different definitions in the literature is that both specific and general cynicism is a negative attitude 
and includes cognitive, emotional, and behavioral elements (Stanley et al., 2005: 452). This negative attitude of individuals can cause various undesirable consequences in organizations. Being with cynical people can be overwhelming while their pessimistic perspectives can damage the relationships of individuals (Dean et al., 1998: 342). Cynical workers do not trust the leaders' actions and authority and they believe that their leaders will exploit them (Mirvis and Kanter, 1989: 380). Studies reveal that cynicism is negatively related to job satisfaction and job performance, decreases organizational commitment, causes alienation, and negatively affects citizenship behavior (Chiaburu et al., 2013: 188; Abraham, 2000: 269; Andersson and Bateman, 1997: 463). In a study conducted by Stanley et al. (2005: 454), cynicism was found to be positively associated with the intention to resist change. Suggesting that negative conditions are more effective than positive ones, Chiaburu et al. (2013: 186) emphasized that cynicism is a much stronger attitude than trust. In their research, they found negative associations between organizational cynicism and positive emotionality, and positive associations with negative emotionality. Many different factors may cause employee cynicism. Having studied the subject in detail, Andersson and Bateman (1997: 450-456) summarize the aforementioned factors in three categories. Work environment characteristics such as incompatibility between practices and policies, unethical behavior and unfair payment policies, organizational characteristics such as lack of employee participation, management incompetence and poor communication, and aspects of the nature of the work such as role conflict, overwork and role ambiguity are among these factors. Apart from these factors, psychological contract is another issue that is frequently emphasized. Psychological contract violations trigger employee cynicism and distrust (Cartwright and Holmes, 2006: 200). Some other factors that cause cynicism have been attributed to issues such as low organizational performance and sudden layoffs (Andersson and Bateman, 1997: 462).

\subsection{Employee Silence}

Pinder and Harlos (2001: 334) defined silence as the absence of voice that includes a series of cognitive, emotional, and behavioral attitudes such as objection or approval. In addition, they stated that silence may have different meanings depending on the motives underlying employee silence. Just like cynicism, silence is quite common in organizations, however, as Morrison and Milliken (2000: 706) stated, it did not receive the research attention it deserved. Today, organizations ask their employees to take more initiative, voice, share information and take responsibility (Shojare et al., 2011: 1731) since communication is critical in achieving organizational goals. Especially the main source of change, innovation and creativity is known as communication. However, silence undermines the positive communication climate in organizations (Bagheri et al., 2012: 55). One of the main factors in the emergence of managerial problems is lack of information as well as lack of communication (Shojare et al., 2011: 1731). For this reason, to examine the nature of silence in organizations and take measures to prevent its negative effects are significant. Being silent is not only a passive behavior but may also occur as a conscious and deliberate action (Pinder and Harlos, 2001: 335). Because most of the time, employees deliberately remain silent to ensure their own safety and act strategically and proactively (Dyne et al., 2003: 1365). In previous studies, different types of silence behavior have been mentioned. According to Dyne at al. (2003: 1362), there are three types of silence based on resignation, fear, and selfpreservation, and being prosocial. These types are known as acquiescent silence, defensive 
silence, and prosocial silence. The acquiescent silence behavior is based on the employee's belief that speaking up will not work and is carried out intentionally. Defensive silence is motivated by active avoidance and self-preservation. Prosocial silence, on the other hand, is motivated by anxiety for others rather than fear of the negative personal consequences that may result from speaking out (Dyne et al., 2003: 1363). While there are some intention differences in the emergence of silence types, silence behavior may also have various reasons. According to Sadeghi and Razavi (2020: 2) a bullying culture can create silence in organizations. On the other hand, Morrison and Milliken (2000: 708) argue that there are generally two reasons for silence in organizations. One is that employees fear that managers will give them negative feedback. The other is the implicit beliefs of managers that employees are lazy, insecure and that disagreements in organizations are wrong (Bagheri et al., 2012: 51). In previous studies the causes of silence and the factors trigger silence were mentioned as individual and organizational factors, perceived organizational and managerial support (Dyne et al., 2003: 1380), cultural power distance (Huang et al., 2005: 472) and the climate of tendency to reject at work (Morrison and Milliken, 2000: 709). An important explanation for the reasons for employee silence can be made based on the "spiral of silence" theory. According to the theory developed by Noelle-Neuman (1991: 258), people will not use their voice unless they are likely to have support from their peers (Bowen and Blockmon, 2003: 1393). Thus, an employee's voice or silence preference is largely determined by the climate of opinion in the work group (Bowen and Blockmon, 2003: 1393). Studies reveal that the silence climate causes undesired consequences in organizations. Morrison and Milliken (2000: 719) interprets organizational silence as a phenomenon that blocks organizational change and development. Silence causes wrong decisions in organizations, negatively affects employee morale, trust, commitment, job satisfaction, and prevents the improvement of organizational processes (Vakola and Bouradas, 2005: 443; Milliken et al., 2003: 3). Organizational silence induces stress, pessimism, and dissatisfaction in employees (Sadeghi and Razavi, 2020: 2). Employee silence negatively affects the psychological well-being of employees, thus paving the way for depression and other psychological problems (Bagheri et al., 2012: 51). As can be seen, previous studies generally evaluate silence as a phenomenon that causes negative and undesirable consequences in organizations.

\subsection{Self-esteem}

Self-esteem is defined as an individual's subjective evaluation of his own worth (Trzesniewski et al., 2013: 60). Apart from subjective evaluation, self-esteem as an attitude or emotional reaction is expressed as a set of personal beliefs about a person's skills, abilities, social relationships, and future expectations (Heatherton and Wyland, 2003: 220). Selfesteem, which is related to people's feelings about themselves, affects their relationships with other people and their environment (Kernis, 2003: 1). People with high self-esteem believe they are intelligent, attractive, and popular (Baumeister et al., 2003: 3) and therefore have more self-confidence than people with low self-esteem (Crocker and Park, 2004: 394). Self-esteem, which has deep and comprehensive effects on emotions and behaviors as a psychological variable, is thought to be of critical importance for the quality of life of the individual (Pyszczybski and Kesebir, 2013: 4). While high self-esteem is assumed to have beneficial effects due to positive self-beliefs, low self-esteem is assumed to have detrimental effects (Crocker and Park, 2004: 392). It is suggested that high self-esteem, which is critical for psychological health (Heatherton and Wyland, 2003: 219), is a cure for many social and 
psychological problems (Leary, 1999: 33). Those with high self- esteem are thought to be less affected by negative experiences and recover from these kinds of experiences more quickly than individual with low self-esteem (Zeigler-Hill, 2013: 2). Jordan and Zeigler-Hill (2013: 80) states that high self-esteem contributes to psychological well-being. Thus, people with high self-esteem can be more successful in various areas (Orth and Robbins, 2014: 384). People with high self-esteem feel better and believe that other people value them where they live. On the contrary, people with low self-esteem see the world through a more negative filter (Heatherton and Wyland, 2003: 219). Low self-esteem is considered as a psychological risk factor as it can leave individuals vulnerable to health problems, while high self-esteem protects the person from health problems as well as supports the health of the person (Stinson et al., 2009: 496). Findings of previous studies also confirm the importance of selfesteem for individuals. Research has shown that low self - esteem is related to psychological and personal problems such as depression, loneliness, substance abuse and criminal behavior (Leary, 1999: 34). High self-esteem is positively associated with mental health, happiness (Furnham and Cheng, 2000: 468) and life satisfaction (Diener and Diener, 2009: 72). In the study conducted by Battle (1978: 746), low self-esteem was found to be associated with depression. Similarly, low self-esteem is positively associated with social anxiety, friendship problems, neuroticism, agreeableness, and social desirability (Crocker and Luhtanen, 2003: 705; Leary et al., 1995: 523). All these findings and the past literature prove that self-esteem is of critical importance in a person's work and social life.

\subsection{Expected Relationships}

\subsubsection{Cynicism and Silence}

The constructs of cynicism and silence are linked, both in terms of their consequences and their causes. Cynicism includes distrust of the manager and authority, high alienation, low job satisfaction, low commitment, poor communication, and withdrawal behavior (Dean et al., 1998: 349-350; Mirvis and Kanter, 1989: 380; Chiaburu et al., 2013: 182; Abraham, 2000: 269; Andersson and Bateman, 1997: 449), coincide with the possible causes of silence behavior in organizations. For instance, cynical employees do not trust leaders' behavior, actions, and authority and believe they will exploit them (Mirvis and Kanter, 1989: 380). A recent study emphasizes bullying culture as one of the possible causes of silence (Sadeghi and Razavi, 2020: 2). Employees are more likely to display silence behavior, as psychological contract violations trigger cynicism and distrust (Cartwright and Holmes, 2006: 200). Studies show that psychological contract violations trigger silence (Rai and Agarwal, 2018: 238; Morsch et al., 2020: 37). In psychology, silence is associated with a lack of self-confidence and introversion (Çakıcı, 2007: 147). Among the reasons for the occurrence of silence, there are beliefs that talking about problems will be unscathed and that sharing ideas and thoughts can be dangerous. In this context, it can be stated that skepticism, insecurity, and risk aversion are common reactions that occur in cynicism and silence. Farjam et al. (2018: 1138) states that cynicism is closely related to job burnout, which plays a role in individuals' decision to silence. In the literature, there are mostly implications for positive relations regarding the relationship between cynicism and silence. On the other hand, it can be stated that empirical studies examining the possible relationship between the two constructs are quite limited. The findings of these limited studies show that there is a positive relationship between cynicism and silence (Mousa et al., 2020: 6; Zhang et al., 2019: 254; Çaylak and Altuntaş, 2017: 95; Altunöz et al., 2017: 77; Kaya, Göncü and Erarslan, 2021: 118). But at this 
point, the reasons for employees to remain silent are also important. In other words, identifying the actual reasons and motives behind such attitudes and behaviors is significant. It is different for cynical people to remain silent because they are submissive or fearful, and that they remain silent to protect others. In the acquiescent and defensive silence, there is an agreement with the suspicion, risk aversion and insecurity features of cynicism. In other words, the negative conditions and emotions created by cynicism push the individual into silence. In this context, it is usual to have a positive relationship between cynicism and acquiescent and defensive silence. On the other hand, silence with the intention of protecting the organization or others is a situation related to altruism. Altruism, cooperation and helping others are expected to be negatively related to cynicism, unlike other types of silence (Roche et al., 2003: 398; Hatfield et al., 2013: 159). The implications for the types of cynicism and silence and the hypotheses developed in line with the findings of previous studies are as follows.

H1: Cynicism is positively related to acquiescent silence.

H2: Cynicism is positively related to defensive silence.

H3: Cynicism is negatively related to prosocial silence.

\subsubsection{Self-esteem and Employee Silence}

Different levels of self-esteem affect the way individuals interpret the events they encounter, their perspective towards life, their attitudes, and behaviors (Kernis, 2003: 1). Individuals with different self-esteem levels may differ in their reactions to the same event. Individuals with high self-esteem are often known as self-confident individuals (Crocker and Park, 2004: 392). Self-confidence and self-esteem are positively associated with vocal behavior rather than being silent (Long et al., 2015: 24; LePine and Dyne, 1998: 853). High self-esteem contributes to the psychological well-being levels of individuals (Jordan and Zeigler-Hill, 2013: 80). Psychological well-being is negatively related to employee silence (Morsch et al., 2020: 7; De los Santos et al., 2020: 782). These situations indicate the existence of a negative relationship between self-esteem and employee silence. Moreover, as stated by Zeigler-Hill (2013: 2), people with high self-esteem are less affected by negative experiences than people with low self-esteem. This means that the employees will be less affected by the negative conditions that cause silence, and thus they will not prefer the behavior of being silent frequently. In this context, the antecedents of silence such as loneliness, bullying culture, fear from the manager and ostracism are expected to have a negative relationship with high self-esteem. On the contrary, employees with low self-esteem are expected to be positively associated with factors that cause silence, due to their tendency to interpret events more negatively (Zeigler-Hill, 2013: 2-3). Because low self-esteem was negatively associated with general negative affectivity, sadness, hostility, anger, social anxiety, guilt, depression, and loneliness (Leary et al., 1995: 523; Battle, 1978: 746). In this context, self-esteem is expected to be negatively related to the acquiescent and defensive silence that arises especially from negative conditions and experiences, but to be positively associated with prosocial silence to protect others. In this direction, the following hypotheses have been formulated in the light of the relevant literature.

H4: Self-esteem is negatively related to acquiescent silence.

H5: Self-esteem is negatively related to defensive silence.

H6: Self-esteem is positively associated with prosocial silence. 


\subsubsection{Cynicism and Self-esteem}

Attitudes of cynical individuals are generally characterized by skepticism, distrust of the environment and self, and negative affectivity (Chiaburu et al., 2013: 188; Dean et al., 1998: 348). The aforementioned traits overlap with those of individuals with low self-esteem. Low self-esteem means employees who have low self-confidence, who think their abilities are useless, who feel worthless, and who do not trust the environment and their organization (Mirvis and Kanter, 1989: 378-380). Chiaburu et al. (2013: 181) found negative associations between cynicism and positive emotionality, and positive relationships with negative emotionality. In this context, high self-esteem is expected to be negatively associated with cynicism, while low self-esteem is expected to be positively associated with cynicism. In other words, as the self-esteem levels of individuals increase, their cynicism levels decrease. The hypothesis created in this direction is as follows.

H7: Cynicism is negatively related to self-esteem.

\subsubsection{Self-esteem as a Moderator}

The positive effects of cynicism on the acquiescent and defensive silence levels of the employees and negative effects on the prosocial silence are usual. However, how these possible interactions occur in the different self-esteem levels of employees and whether there is any moderating effect of self-esteem in the mentioned interactions are questions that need to be answered. In fact, previous studies in the literature reflect that self-esteem can be a very strong moderator variable (Longmore and Demaris, 1997; Mossholder et al., 1982; Feng and Xu, 2015; Ferris et al., 2010). In these studies, the moderating effect of self-esteem among variables such as perceived inequality and depression (Longmore and Demaris, 1997: 180), intention to quit, performance and tension (Mossholder et al., 1982: 580) and perceived discrimination and psychological stress were questioned, and significant findings have been obtained. Moreover, behavioral plasticity theory offers strong implications that self-esteem can be a powerful moderator variable (Brockner, 1988 cited in Ferris et al., 2010: 563). In theory, high self-esteem can act as a resource and providing a buffer against negative conditions and reducing their impact. Adversely individual with low self-esteem lack such a buffer and hence more affected by negative conditions (Brockner, 1988 cited in Ferris et al., 2010: 564). Therefore, the effects of negative emotional conditions such as cynicism are expected to be felt stronger in individuals with low self-esteem, and weaker in individuals with high self-esteem. In this context, it seems normal that self-esteem has a negative moderating effect in the possible associations between cynicism and acquiescent and defensive silence. On the other hand, in the possible negative relationship between cynicism and prosocial silence, self-esteem is expected to have a positive moderating effect. The following hypotheses have been formulated based on the implications of previous studies and the emphasis of the behavioral plasticity theory.

H8: Self-esteem has a negative moderating effect in the positive association between cynicism and acquiescent silence.

H9: Self-esteem has a negative moderating effect in the positive association between cynicism and defensive silence.

H10: Self-esteem has a positive moderating effect in the negative association between cynicism and prosocial silence. 


\subsection{Research model}

The model created based on the research hypotheses is shown in Figure 1. In order to avoid a complex view, the model is shown in three different figures based on the types of silence. Naturally, only $\mathrm{H} 7$ repeated in all three figures.

Figure 1: Research Model
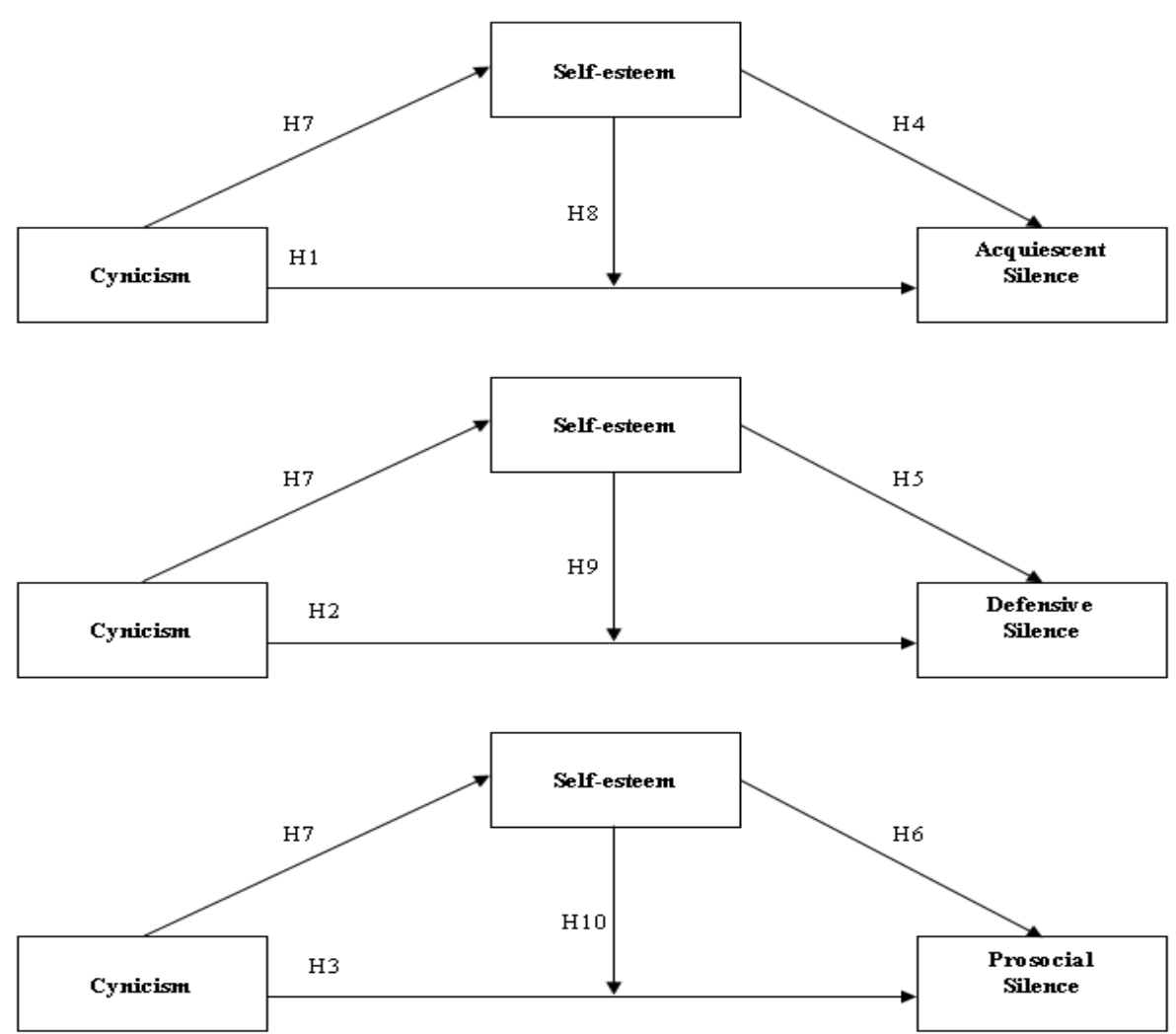

\section{Method}

\subsection{Participants and procedure}

The quantitative method was adopted in the study. The data required for the research were obtained by the online questionnaire technique. A questionnaire was created through an online survey website and a link was generated for distribution. The link was delivered to the employees via e-mail and social media, and they were asked to participate in the study voluntarily. Since there was no sector comparison or a sector-focused research was not aimed, the easy sampling method was applied. Links were sent to approximately 750 employees and 535 responses were received. 13 incorrectly filled questionnaires were cancelled and 522 questionnaires were found be suitable for analysis. Therefore, the sample of the study consists of 522 participants working mainly in the education, health, automotive, and food sectors in the Marmara Region of Turkey. 


\subsection{Measures}

All scales used in the study are Likert type. Scale using permissions for each scale were obtained from the researchers who made the adaptations to the local language. Since there were no reverse items in original cynicism and organizational silence scales, reverse control items for each were added. Demographic characteristics of employees were also measured including gender, marital status, education level, monthly income, and age.

\subsubsection{Cynicism}

A 10-item scale was used to measure cynicism levels of employees which was developed by Wrightsman (1992). Validity and reliability procedures of Turkish version were conducted by Akbolat et al. (2014). Each item is rated from 1 "strongly disagree" to 5 "strongly agree". Sample items are "People pretend to care about one another more than they really do" and "People claim that they have ethical standards of honesty and morality, but few people stick to them when the chips are down".

\subsubsection{Organizational Silence}

A 15-item organizational silence scale developed by Dyne et al. (2003) was used to capture the employees' silence behaviors. The scale was adapted to Turkish by Taşkıran (2010). Items are categorized in three subscales as acquiescent silence, defensive silence, and prosocial silence. Each item is rated from 1 "strongly disagree" to 5 "strongly agree". Sample items are "I passively withhold ideas, based on resignation" and "I protect proprietary information in order to benefit the organization".

\subsubsection{Self-Esteem}

A 10-item self-esteem scale developed by Rosenberg (1965) was used to measure the employees' self-esteem levels. The scale was adapted to Turkish by Çuhadaroğlu (1986). Each item is rated from 1 "strongly disagree" to 4 "strongly agree". Half of items are reverse coded. Sample items are "I am able to do things as well as most other people" and "I wish I could have more respect for myself".

\section{Results}

Before hypotheses testing, findings related to reliability, validity, and descriptive statistics of scales with demographic features of participants were examined. For reliability, internal consistency tests and for validity confirmatory factor analyses were applied. Independent samples t-tests and one-way Anova analysis were also conducted in order to observe the differences between demographic features of participants in terms of research variables.

\subsection{Reliability and Validity}

First, reliability analyses were applied and during the process total item correlations of each scale were examined. Only one item was excluded from self-esteem scale since it was quite low (i.e., .06). At the end of analyses internal consistency coefficients were obtained as $\alpha=.823$ for cynicism, $\alpha=.902$ for self-esteem, $\alpha=.834$ for acquiescent silence, $\alpha=.919$ for defensive silence and $\alpha=.898$ for prosocial silence.

CFA is used to test the factor structure of cynicism, self-esteem, acquiescent silence, defensive silence, and prosocial silence scales. First of all, CFA was applied for each scale separately and after that all scales were evaluated as a whole construct (five factor model). 10 item cynicism scale fit the data well (x2/df: 2.78; GFI: .96; CFI: .95; RMSEA: .05). The factor 
structure of 9 item self-esteem scale was not fit the data very well because fit indices were below expectations (x2/df: 20.76; GFI: .79; CFI: .80; RMSEA: .19). This result may be due to the fact that half of the scale items are reverse coded. And therefore, there may have been slight deviations in the responses of the participants. On the other hand, the internal consistency coefficient of the scale was found to be quite reliable as mentioned above $(\alpha=$ .902). 15 item organizational silence scale with three factors also fit the data well (x2/df: 3.53; GFI: .93; CFI: .96; RMSEA: .07). After all, the five-factor model fit the data well since fit indices were also satisfactory level (x2/df: 3.08; GFI: .83; CFI: .89; RMSEA: .06). Internal consistency coefficients and CFA results are shown in Table 1.

Table 1: Reliability and CFA Results

\begin{tabular}{|c|c|c|c|c|}
\hline Scale/Model & $\begin{array}{l}\text { Number } \\
\text { of Items }\end{array}$ & $\begin{array}{l}\text { Number } \\
\text { of Factor }\end{array}$ & $\begin{array}{c}\text { Cronbach's } \\
\text { Alpha }\end{array}$ & Fit Indices \\
\hline Cynicism & 10 & 1 & .823 & x2/df: 2.78; GFI: .96; CFI: .95; RMSEA: .05 \\
\hline Self-esteem & 9 & 1 & $\begin{array}{c}.902 \\
\text { A. S. } .834\end{array}$ & x2/df: 20.76; GFI: .79; CFI: .80; RMSEA: .19 \\
\hline Organizational Silence & 15 & 3 & $\begin{array}{l}\text { D. S. } .919 \\
\text { P. S. } .898\end{array}$ & x2/df: 3.53; GFI: .93; CFI: .96; RMSEA: .07 \\
\hline Five-factor model & 34 & 5 & - & x2/df: 3.08; GFI: .83; CFI: .89; RMSEA: .06 \\
\hline
\end{tabular}

AS=Acquiescent Silence, DS=Defensive Silence, PS= Prosocial Silence. For CFA visuals please see Appendixes.

\subsection{Descriptive Statistics and Demographic Features of Participants}

Table 2 indicates the descriptive statistics of scales and demographic features of participants in detail.

Table 2: Descriptive Statistics and Demographics

\begin{tabular}{|c|c|c|c|c|c|c|}
\hline $\begin{array}{l}\text { Demographic } \\
\text { Features }\end{array}$ & N (\%) & $\begin{array}{l}\text { Cynicism } \\
\text { Mean (SD) }\end{array}$ & $\begin{array}{l}\text { Self-Esteem } \\
\text { Mean (SD) }\end{array}$ & $\begin{array}{l}\text { Acquiescent } \\
\text { Silence } \\
\text { Mean (SD) }\end{array}$ & $\begin{array}{l}\text { Defensive } \\
\text { Silence } \\
\text { Mean (SD) }\end{array}$ & $\begin{array}{l}\text { Prosocial } \\
\text { Silence } \\
\text { Mean (SD) }\end{array}$ \\
\hline Gender & & $\mathrm{t}=1.23 ; \mathrm{p}=0.20$ & $\mathrm{t}=-1.34 ; \mathrm{p}=$ & $t=0.33 ; p=0.74$ & $t=0.33 ; p=0.74$ & $t=-1.75 ; p=0.08$ \\
\hline Female & $263(50.4)$ & $3.50(0.70)$ & 0.218 & $2.39(0.92)$ & $2.35(1.08)$ & $3.65(1.17)$ \\
\hline Male & $259(49.6)$ & $3.42(0.70)$ & $\begin{array}{l}2.96(0.73) \\
3.04(0.61)\end{array}$ & $2.36(0.93)$ & $2.11(0.96)$ & $3.82(1.07)$ \\
\hline Marital Status & & $t=-2.96 ; p=0.00$ & $\mathrm{t}=4.29 ; \mathrm{p}=0.00$ & $\mathrm{t}=-3.28 ; \mathrm{p}=0.00$ & $t=-5.26 ; p=0.00$ & $t=3.18 ; p=0.00$ \\
\hline Single & $254(48.7)$ & $3.36(0.75)$ & $3.13(0.61)$ & $2.25(0.81)$ & $1.99(0.89)$ & $3.89(0.99)$ \\
\hline Married & $268(51.3)$ & $3.54(0.63)$ & $2.88(0.71)$ & $2.49(0.91)$ & $2.46(1.11)$ & $3.59(1.21)$ \\
\hline Education Level & & $F=1.58 ; p=0.18$ & $F=5.85 ; p=0.00$ & $F=9.11 ; p=0.00$ & $F=4.41 ; p=0.00$ & $F=8.53 ; p=0.00$ \\
\hline Primary Sch. & $30(5.7)$ & $3.22(0.96)$ & $2.74(0.72)$ & $2.81(0.79)$ & $2.44(0.86)$ & $3.39(1.23)$ \\
\hline High School & $116(22.2)$ & $3.53(0.66)$ & $2.83(0.77)$ & $2.65(0.88)$ & $2.44(1.08)$ & $3.38(1.24)$ \\
\hline Associate & $77(14.8)$ & $3.53(0.71)$ & $2.93(0.76)$ & $2.46(0.89)$ & $2.45(1.28)$ & $3.49(1.38)$ \\
\hline Bachelor's & $239(45.8)$ & $3.43(0.65)$ & $3.08(0.56)$ & $2.24(0.84)$ & $2.11(0.92)$ & $3.96(0.91)$ \\
\hline Graduate & $60(11.5)$ & $3.46(0.69)$ & $3.21(0.64)$ & $2.04(0.77)$ & $1.94(0.98)$ & $4.04(0.93)$ \\
\hline Monthly Inc. (f) & & $F=2.08 ; p=0.13$ & $F=16.20 ; p=$ & $F=25.02 ; p=0.00$ & $F=29.85 ; p=0.00$ & $F=21.33 ; p=0.00$ \\
\hline $225-400$ & $82(15.7)$ & $3.53(0.73)$ & 0.00 & $2.89(0.97)$ & $2.81(1.20)$ & $3.35(1.31)$ \\
\hline $401-600$ & $88(16.9)$ & $3.56(0.62)$ & $2.74(0.76)$ & $2.57(0.88)$ & $2.60(1.05)$ & $3.24(1.25)$ \\
\hline 601 and above & $352(67.4)$ & $3.41(0.70)$ & $2.79(0.76)$ & $2.21(0.79)$ & $2.01(0.90)$ & $3.95(0.97)$ \\
\hline & & & $3.11(0.60)$ & & & \\
\hline Age & & $F=9.00 ; p=0.00$ & $F=15.82 ; p=$ & $F=8.96 ; p=0.00$ & $F=14.16 ; p=0.00$ & $F=5.46 ; p=0.00$ \\
\hline $18-30$ & $266(51.0)$ & $3.60(0.62)$ & 0.00 & $2.58(0.94)$ & $2.54(1.15)$ & $3.52(1.29)$ \\
\hline $31-35$ & $78(14.9)$ & $3.46(0.63)$ & $2.78(0.75)$ & $2.21(0.80)$ & $2.05(0.88)$ & $4.02(0.78)$ \\
\hline $36-40$ & $68(13.0)$ & $3.32(0.73)$ & $3.23(0.53)$ & $2.16(0.70)$ & $1.87(0.67)$ & $3.89(0.92)$ \\
\hline $41-45$ & $29(5.6)$ & $3.41(0.78)$ & $3.25(0.57)$ & $2.32(0.77)$ & $1.91(0.84)$ & $3.90(0.92)$ \\
\hline 46 and above & $81(15.5)$ & $3.11(0.79)$ & $3.14(0.43)$ & $2.04(0.70)$ & $1.81(0.73)$ & $4.00(0.86)$ \\
\hline & & & $3.23(0.42)$ & & & \\
\hline Sector & & $t=-0.97 ; p=0.33$ & $t=1.61 ; p=0.11$ & $\mathrm{t}=-1.13 ; \mathrm{p}=0.25$ & $t=-1.44 ; p=0.15$ & $t=-0.41 ; p=0.68$ \\
\hline Public & $133(25.5)$ & $3.40(0.73)$ & $3.08(0.65)$ & $2.30(0.84)$ & $2.12(0.98)$ & $3.70(1.12)$ \\
\hline Private & $389(74.5)$ & $3.47(0.68)$ & $2.97(0.68)$ & $2.40(0.88)$ & $2.27(1.05)$ & $3.75(1.12)$ \\
\hline
\end{tabular}


Participants were almost equal in terms of gender and marital status. Most of participants had bachelor's degree education, earned more than $600 €$ income per month, between 18-30 age and worked in private sector. There were no significant differences between male and female employees and employees working in public versus private sectors in terms of cynicism, self-esteem, or any type of silence levels. On the other hand, there were statistically differences depending on employees' other features. For instance, single employees were found to have higher self-esteem than married ones. Self-esteem increased as the education level increased, so graduate level employees had highest self-esteem, among others. Similarly, as the monthly income increased, self-esteem also increased, and employees earned more than $600 €$ were found to have highest self-esteem. The details regarding other features are presented in Table 1.

\subsection{Correlations}

To test first seven hypothesis correlation analysis were conducted. Table 3 shows the correlations among research variables and some demographic features. Cynicism was found to be positively related to both acquiescent $\left(r=.19^{* *} ; p<.01\right)$ and defensive silence $\left(r=.16^{* *}\right.$; $p<.01)$, but negatively related to prosocial silence $(r=.10 * ; p<.05)$. While self-esteem was found to have strong negative associations with acquiescent $\left(r=-.61^{* *} ; p<.01\right)$ and defensive silence $(r=-.62 * * ; p<.01)$, have positive association with prosocial silence $\left(r=.57^{* *} ; p<.01\right)$. Another finding indicated a negative association between cynicism and self-esteem $\left(r=-.22^{* *}\right.$; $\mathrm{p}<.01$ ). Thus, $\mathrm{H1}, \mathrm{H} 2, \mathrm{H} 3, \mathrm{H} 4, \mathrm{H} 5, \mathrm{H} 6$ and $\mathrm{H} 7$ were all supported.

Table 3: Correlations among Variables

\begin{tabular}{lcccccccccr}
\hline Variables & $\mathbf{1}$ & $\mathbf{2}$ & $\mathbf{3}$ & $\mathbf{4}$ & $\mathbf{5}$ & $\mathbf{6}$ & $\mathbf{7}$ & $\mathbf{8}$ & $\mathbf{9}$ & $\mathbf{1 0}$ \\
\hline 1. Gender & - & & & & & & & & \\
2. Marital & $-.18^{* *}$ & - & & & & & & & \\
Status & & & & & & & & \\
3. Education & -.05 & $.12^{* *}$ & - & & & & & & \\
4. Age & $.24^{* *}$ & $-.58^{* *}$ & $-.10^{*}$ & - & & & & & \\
5. Monthly & $.31^{* *}$ & $-.36^{* *}$ & $.18^{* *}$ & $.35^{* *}$ & - & & & & \\
Inc. & -.06 & $.13^{* *}$ & -.00 & $-.25^{* *}$ & -.08 & - & & & \\
6. C & .06 & $-.18^{* *}$ & $.21^{* *}$ & $.26^{* *}$ & $.23^{* *}$ & $-.22^{* *}$ & - & & & \\
7. SE & -.01 & $.14^{* *}$ & $-.26^{* *}$ & $-.23^{* *}$ & $-.30^{* *}$ & $.19^{* *}$ & $-.61^{* *}$ & - & & \\
8. AS & $-.11^{* *}$ & $.22^{* *}$ & $-.17^{* *}$ & $-.28^{* *}$ & $-.31^{* *}$ & $.16^{* *}$ & $-.62^{* *}$ & $.72^{* *}$ & - & \\
9. DS & .08 & $-.14^{* *}$ & $.23^{* *}$ & $.16^{* *}$ & $.24^{* *}$ & $-.10^{*}$ & $.57^{* *}$ & $-.48^{* *}$ & $-.55^{* *}$ & - \\
10. PS & & & & & & & & & & \\
\hline
\end{tabular}

${ }^{*} \mathrm{p}<.05,{ }^{* *} \mathrm{p}<.01 . \mathrm{N}=431$. Gender: 1=Female, 2= Male. Marital status: 1=Married, 2=Single. C=Cynicism, SE=SelfEsteem, AS=Acquiescent Silence, DS=Defensive Silence, PS= Prosocial Silence.

\subsection{Moderating Effect of Self-Esteem}

In order to test H8, H9 and H10, Hayes (2013) moderation analysis method was conducted. In this method, both the direct effects of independent variables and the moderating effect of moderator variable can be observed. In this technique, three points are determined as low, medium, and high depending on mean standard deviation of moderator variable (i. e. Mean SD of SE-1=Low, Mean SD of SE=Medium and Mean SD of SE+1=High). Thus, the coefficient differences in the effect of independent variables on dependent variables at high, medium, and low points are examined. Based on above mentioned procedure three models were created. In first model, the moderating effect of self-esteem in 
the association between cynicism and acquiescent silence and in second model, the moderating effect of self-esteem in the association between cynicism and defensive silence were tested. Subsequently in third model, the moderating effect of self-esteem in the association between cynicism and prosocial silence was examined. Table 4 shows the results the moderating effects of self- esteem.

Table 4: Moderating Effects of Self-Esteem

\begin{tabular}{|c|c|c|c|c|c|c|c|}
\hline Model & DV & $\mathrm{IV}$ and $\mathrm{MV}$ & B (se) & $\mathbf{t}$ & $\mathbf{p}$ & $95 \% \mathrm{Cl}$ & $F(d f 1-d f 2)$ \\
\hline & & C & $.05(.04)$ & 1.45 & .15 & {$[-.02 ; .12]$} & \\
\hline \multirow[t]{3}{*}{1} & AS & SE & $-.52 * *(.03)$ & -15.00 & .00 & {$[-.59 ;-.45]$} & $87.53(3-518)$ \\
\hline & & CXSE & $.02(.03)$ & .60 & .55 & {$[-.04 ; .08]$} & \\
\hline & & C & $.04(.04)$ & .84 & .40 & {$[-.05 ; .12]$} & \\
\hline \multirow[t]{3}{*}{2} & DS & SE & $-.63 * *(.04)$ & -14.38 & .00 & {$[-.71 ;-.54]$} & $82.70(3-518)$ \\
\hline & & $\mathrm{C} \times \mathrm{SE}$ & $-.03(.04)$ & -.61 & .54 & {$[-.11 ; .06]$} & \\
\hline & & C & $.04(.04)$ & .94 & .35 & {$[-.04 ; .12]$} & \\
\hline \multirow[t]{2}{*}{3} & PS & SE & $.64^{* *}(.04)$ & 15.20 & .00 & {$[.55 ; .72]$} & $85.52(3-518)$ \\
\hline & & $\mathrm{C} \times \mathrm{SE}$ & $.08 *(.04)$ & 2.00 & .04 & {$[.00 ; .16]$} & \\
\hline
\end{tabular}

${ }^{*} \mathrm{p}<.05,{ }^{* *} \mathrm{p}<.01 . \mathrm{N}=522$. DV= Dependent variable, IV= Independent variable, MV: Moderator, C= Cynicism, SE= SelfEsteem, AS= Acquiescent Silence, DS= Defensive Silence, PS= Prosocial Silence.

Even the though the positive associations between cynicism and acquiescent and defensive silence were obtained in correlation analysis, those significant associations were disappeared in moderation analysis in model 1 and 2 . Results indicated that there were no moderating effects of self-esteem in expected two models $[(\beta=.05 ; p>.05),(\beta=-.03 ; p>.05)]$. However, in model 3 , the moderating effect of self-esteem in the association between cynicism and prosocial silence was observed $\left(\beta=.08^{*} ; p<.05\right)$. Accordingly, while $\mathrm{H} 8$ and $\mathrm{H} 9$ were not supported, $\mathrm{H} 10$ was supported. Figure 2 shows the moderating effect of self-esteem in the association between employee cynicism and prosocial silence.

Figure 2: Moderating Effect of Self-Esteem in the Association between Employee Cynicism and Prosocial Silence

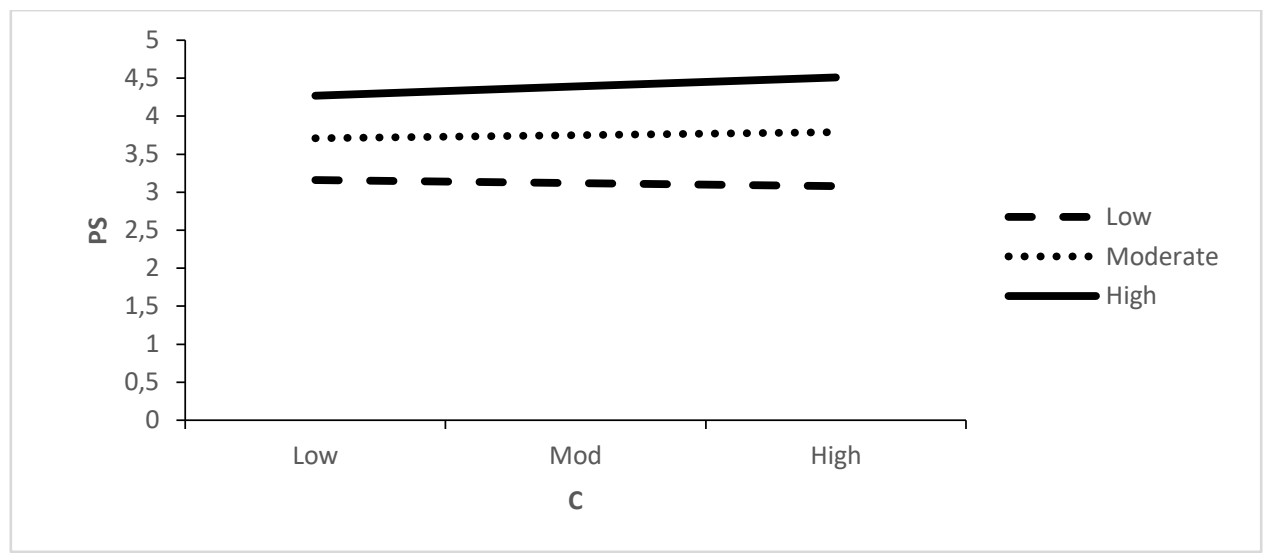




\section{Discussion and Conclusion}

In current study the associations between cynicism and types of silence and the potential moderating effects of self-esteem in these expected associations were investigated. As a result of research, cynicism was found to be positively related to acquiescent and defensive silence, while it was negatively related to prosocial silence. These results are mostly consistent with the findings of previous research (Altınöz et al., 2017; Çaylak and Altuntaş, 2017; Demirtaş et al., 2016; Erdoğdu, 2018; Kalay et al., 2012; Kaya, et al., 2021; Mousa et al., 2020). But most of that research did not mention the different types of silence, and silence was examined as a whole structure. For instance, even Erdoğdu (2018) adopted the Dyne et al., (2003: 1363)'s silence dimensions, didn't provide any information about prosocial silence. Similarly, Çaylak and Altuntaş (2017: 94) found positive associations between reasons for remaining silent and employee cynicism, however they did not mention any reason for prosocial intentions. In a recent study, acquiescent and defensive silence were found to be positively associated to cynicism while prosocial silence was negatively associated to cynicism (Kaya et al., 2021: 117). This finding is fully consistent with current study's results. On the other hand, a negative relationship between cynicism and silence was observed in Farjam et al. (2018: 1150)'s study. This unique finding contrary to literature is also not consistent with this study's findings. All acquiescent, defensive and prosocial silences were found to be positively related to cynicism in a study (Karacaoğlu and Küçükköylü, 2015: 406). While the first two findings are consistent, finding related to prosocial silence is inconsistent with current study' results. In cynicism mistrust, skepticism and lack of self-confidence are common. These psychological conditions are satisfying reasons for employees to submit, fear and withdraw themselves. In this respect, it is normal for employees to prefer to remain silent who are skeptical and suspicious of their surroundings. Because for employees, being silent may be sometimes more significant than talking and the possibility of getting hurt. The positive associations between cynicism and acquiescent and defensive silence can be explained in this way. On the other hand, being silent to help others is a matter with a different psychological background. In fact, remaining silent or not speaking out to help others is not about the mistrust or skepticism inherent in cynicism, but about altruism. Since helping others and altruism behaviors are already characteristic of mentally healthy people in psychology, the negative relationship of prosocial silence to cynicism is commonplace. At this point it is critical to understand what is the mental pattern that causes the silence intention and why employees prefer to remain silent.

Another finding indicates a positive correlation between cynicism and self-esteem. People with low self-esteem tend to evaluate all events negatively. On the other hand, individuals with high self-esteem draw a more optimistic and positive profile due to their merits such as self-confidence and self-efficacy. Since the positive psychological aspect of high self-esteem does not coincide with the negative nature of cynicism, employees with increased self-esteem will be less or not affected by the negative aspects of cynicism. Therefore, as self-esteem increases, employees' power to avoid cynical attitudes and eliminate the negative effects of cynicism also increases. The negative correlation between cynicism and self-esteem can explained in this way. Limited previous research is also consistent with this study's findings (Lam, 2011: 29; Guastello et al., 1982: 37; Lai et al., 2007: 524). For instance, in a two-study research, participants with a cynical worldview were more likely to report lower self-esteem (Lam, 2011: 3). Self-esteem is also negatively related to acquiescent and defensive silences 
while it is positively related to prosocial silence. Employees with high self-confidence are not expected to remain silent based on submission or fear. On the contrary, it is more reasonable for employees with high self-esteem to behave more objection and voice. Moreover, it can be explained that employees with high self-esteem have higher helping behaviors for others and therefore remain prosocial silent. It is normal for a positive psychological mood to reflect on oneself as well as on others.

Unlike the behavioral plasticity theory, in current study the moderating effects of selfesteem in cynicism-acquiescent and cynicism-defensive silence associations were not observed. These results may be as a result of both acquiescent and defensive silence are largely explained by cynicism. However, a weak moderating effect of self-esteem in the association between cynicism and prosocial silence was achieved. It means that self-esteem play a buffer role and cynical employees with high self-esteem exhibits more prosocial silence. Behavioral plasticity theory asserts that high self-esteem provides a buffer against negative conditions and reducing their impact. Adversely individual with low self-esteem lack such a buffer and hence more affected by negative conditions (Brockner, 1988 cited in Ferris et al., 2010: 564). The implications of theory and previous research findings received little support within the context of current study. For instance, Amah and Okafor (2008: 7) found a moderating effect of self-esteem in the relationship between silence climate and silence behavior and so they argued that this result was an indication of individual differences (i. e. self-esteem) must be considered in any silence model.

As a conclusion, self-esteem is a significant variable which has strong associations with work attitudes and behaviors (i. e. cynicism, employee silence) and may be a certain predictor of other critical work outcomes with its benefits and harms. However, it is not an individual trait with extremely significant effects as exaggerated in the literature.

There may be some limitations of this study. First, this study was carried out on employees working in only Marmara Region of Turkey (Istanbul, Kocaeli and Sakarya). Although the sample size is satisfactory, the findings cannot be generalized to other countries. Turkey is mostly characterized by high power distance and collectivist cultural values. Cultural values may affect the perceptions, attitudes, and behaviors of people in different societies. For instance, an authority figure may trigger employees' cynicism and silence levels in a low power distance society, while it may be evaluated as an ordinary case and may not have any significant effects. Second limitation is related to data gathering. Due to pandemic restrictions, the surveys were obtained only online. Almost half of the sample consists of young people between 18-30 ages. Such a situation may have arisen due to the fact that young people are more adapted to online interactions and older ones less willing to participate to the research. Other limitation is about the scope of employee silence. In present study employee cynicism was evaluated as a whole structure rather than focusing on its dimensions such as cognitive, affective and behavioral. Another limitation is about the scope of cynicism. In present study general cynicism level of employees was measured in generally rather than focusing organizational cynicism. The last constraint of the study is that there is no sector comparison since it is not the aim of the study.

The results of current study present some implications for academics and practitioners. The association between cynicism and silence differs according to the types of silence. In this context, organizations should first investigate why their employees remain silent and shape their action plans accordingly. For instance, being silent for the benefit of colleagues does not 
reflect the negativity of employee psychology, while acquiescent silence may indicate a negative psychological disorder. The organizational consequences of the two situations may differ. This situation will also be useful in understanding the psychological mental structure of the employees. The strong negative associations of self-esteem with acquiescent, defensive silences, and cynicism reveal that self-esteem is a significant employee feature. That is why it may be beneficial for organizations to prefer people with high self-esteem, especially in recruitment and rank promotions. In addition, self-esteem can be evaluated as a tool in repairing the communication environment damaged by cynicism and silence. In order to get away from the insecure business environment created by cynicism and silence, establishing systems that will make communication open, guarantee the rights and freedoms of people and supporting these systems with laws will be useful in preventing possible organizational problems. There is still a need for new studies about individuals' intentions of silence and its relations with other work-related outcomes. Especially, research examine the intentions of silence separately are quite limited in the literature. This is also significant in order to better understand employee nature. Present study was conducted in a country characterized by high power distance and collectivist cultural values. Performing a similar study in different societies where individualistic and low power distance values prevail may be useful in terms of allowing intercultural comparison. Studies on the moderator effect of self-esteem are almost nonexistent in the literature. Although it is concluded that self-esteem is not as significant a variable as it is exaggerated in the context of this study, it is obvious that more new studies are still needed. 


\section{References}

Abraham, R, (2000), "Organizational Cynicism: Bases and Consequences", Genetic, Social, and General Psychology Monographs, Vol. 126, No. 3: 269-92.

Akbolat, M., Işık, O., \& Kahraman, G. (2014), "Sağlık Çalışanlarının Sinik Davranışlar Gösterme Eğilimi", Kastamonu Üniversitesi iktisadi ve Idari Bilimler Fakültesi Dergisi, C. 4, S. 2: 84-95.

Altınöz, M., Çakıroğlu, D., Çöp, S., \& Kahraman, E. (2017), "Örgütsel Sessizliğin Ögütsel Sinizm üzerine Etkisi: Bir Alan Araştırması", Electronic Journal of Vocational Colleges, C.7, S. 2: 73-79.

Amah, O. E. \&, Okafor, C. A. (2008), "Relationships Among Silence Climate, Employee Silence Behaviour and Work Attitudes: The Role of Self-Esteem and Locus of Control", Asian Journal of Scientific Research, Vol. 1, No. 1: 1-11.

Andersson, L. M., \& Bateman, T. S. (1997), "Cynicism in the workplace: some causes and effects", Journal of Organizational Behavior, Vol. 18, No. 5: 449-469. https://doi.org/10.1002/(SICI)10991379(199709)18:5<449::AID-JOB808>3.0.CO;2-O.

Bagheri, G., Zarei, R., \& Aeen, M. N. (2012), "Organizational Silence: Basic Concepts and Its Development Factors", Ideal Type of Management, Vol. 1, No. 1: 47-58.

Battle, J. (1978), "Relationship between Self-Esteem and Depression", Psychological Reports, Vol. 42, No. 3: 745-746. doi:10.2466/pr0.1978.42.3.745.

Baumeister, R. F., Campbell, J. D., Krueger, J. I., \& Vohs, K. D. (2003), “Does High Self-Esteem Cause Better Performance, Interpersonal Success, Happiness, or Healthier Lifestyles?", Psychological Science in the Public Interest, Vol. 4, No. 1: 1-44. https://doi.org/10.1111\%2F1529-1006.01431.

Bowen, F., \& Blackmon, K. (2003), "Spirals of Silence: The Dynamic Effects of Diversity on Organizational Voice", Journal of Management Studies, Vol. 40, No. 6: 13931417. https://doi.org/10.1111/1467-6486.00385.

Brockner, J. (1988), "Issues in organization and management series. Self-esteem at work: Research, theory, and practice", Lexington Books/D. C. Heath and Com.

Çakıcı, A. (2007), "Örgütlerde Sessizlik: Sessizliğin Teorik Temelleri ve Dinamikleri", Ç.Ü. Sosyal Bilimler Enstitüsü Dergisi, C. 16, S. 1: 145-162.

Cartwright, S., \& Holmes, N. (2006), "The meaning of work: The challenge of regaining employee engagement and reducing cynicism", Human Resource Management Review, Vol. 16, No. 2: 199-208. https://doi.org/10.1016/j.hrmr.2006.03.012.

Çaylak, E., \& Altuntaş, S. (2017), “Organizational Silence Among Nurses: The Impact on Organizational Cynicism and Intention to Leave Work", Journal of Nursing Research, Vol. 25, No. 2: 90-98 doi: 10.1097/JNR.0000000000000139.

Chiaburu, D. S., Peng, A. C., Oh, i. S., Banks, G. C., \& Lomeli, L. C. (2013), "Antecedents and consequences of employee organizational cynicism: A meta-analysis", Journal of Vocational Behavior, Vol. 83, No. 2: 181-197. https://doi.org/10.1016/j.jvb.2013.03.007.

Crocker, J., \& Luhtanen, R. K. (2003), "Level of Self-Esteem and Contingencies of Self-Worth: Unique Effects on Academic, Social, and Financial Problems in College Students", Personality and Social Psychology Bulletin, Vol. 29, No. 6: 701-712. https://doi.org/10.1177\%2F0146167203029006003.

Crocker, J., \& Park, L. E. (2004), "The Costly Pursuit of Self-Esteem", Psychological Bulletin, Vol. 130, No. 3: 392-414. https://doi.org/10.1037/0033-2909.130.3.392.

Çuhadaroğlu, F. (1986), "Adolesanlarda Benlik Saygııı", Uzmanlık Tezi, Hacettepe Üniversitesi Tıp Fakültesi Psikiyatri Anabilim Dalı, Ankara.

De los Santos, J. A. A., Rosales, R. A., Falguera, C. C., Firmo, C. N., Tsaras, K., \& Labrague, L. J. (2020), "Impact of organizational silence and favoritism on nurse's work outcomes and psychological wellbeing", Nursing Forum, Vol. 55, No. 4: 782- 792. https://doi.org/10.1111/nuf.12496.

Dean, J. W., Brandes, P., \& Dharwadkar, R. (1998), "Organizational Cynicism", The Academy of Management Review, Vol.23, No. 2: 341-352. https://doi.org/10.5465/amr.1998.533230. 
Demirtaş, Z., Özdemir, T. Y., \& Küçük, Ö. (2016), “Okulların Bürokratik Yapısı, Örgütsel Sessizlik ve Örgütsel Sinizm Arasındaki Ilişki", Kuram ve Uygulamada Eğitim Yönetimi, C. 22, S. 2: 193-216.

Diener E., \& Diener M. (2009), "Cross-Cultural Correlates of Life Satisfaction and Self-Esteem", Culture and Well-Being. Social Indicators Research Series, (Ed. E. Diener) Vol. 38, Springer, Dordrecht. https://doi.org/10.1007/978-90-481-2352-0_4.

Dyne, L.V., Ang, S., \& Botero, I.C. (2003), "Conceptualizing Employee Silence and Employee Voice as Multidimensional Constructs", Journal of Management Studies, Vol. 40, No. 6: 1359-1392. http://dx.doi.org/10.1111/1467-6486.00384.

Erdoğdu, M. (2018), "Effect of Organizational Justice Behaviors on Organizational Silence and Cynicism: A Research on Academics from Schools of Physical Education and Sports", Universal Journal of Educational Research, Vol. 6, No. 4: 733-741. https://doi.org/10.13189/ujer.2018.060416.

Farjam, S., Almodarresi, S. M. A., Pirvali, E., Saberi, H., \& Malekpour, S. (2018), "The mediator effect of occupational burnout on the relationship between organizational cynicism and organizational silence (Case of study: employees of Farokhshahr social security organization hospital)", Revista Publicando, Vol. 15, No. 2: 1136-1159.

Feng, D., \& Xu, L. (2015), "The relationship between perceived discrimination and psychological distress among Chinese pulmonary tuberculosis patients: The moderating role of self-esteem", Psychology, Health \& Medicine, Vol. 20, No. 2: 177-185. https://doi.org/10.1080/13548506.2014.958505.

Ferris, D. L., Lian, H., Brown, D. J., Pang, F. X. J., \& Keeping, L. M. (2010), "Self-esteem and Job Performance: The Moderating Role of Self-esteem Contingencies", Personnel Psychology, Vol. 63, No. 3: 561-593. https://doi.org/10.1111/j.1744-6570.2010.01181.x.

Furnham, A., \& Cheng, H. (2000), "Perceived parental behaviour, self-esteem and happiness", Social Psychiatry and Psychiatric Epidemiology, Vol. 35: 463-470. https://doi.org/10.1007/s001270050265.

Guastello, S. J., Rieke, M. L., Guastello, D. D., \& Billings, S. W. (1992), "A Study of Cynicism, Personality, and Work Values", The Journal of Psychology, Vol. 126, No. 1:37-48. https://doi.org/10.1080/00223980.1992.10543339.

Hatfield, R. D., Turner, J. H., \& Spiller, S. (2013), “Altruism, Reciprocity, and Cynicism: A New Model to Conceptualize the Attitudes Which Support Prosocial Behaviors", Journal of Organizational Culture, Communications and Conflict, Vol. 17, No. 2: 159-165.

Hayes, A. F. (2013), "Methodology in the social sciences. Introduction to mediation, moderation, and conditional process analysis: A regression-based approach", Guilford Press.

Heatherton, T. F., \& Wyland, C. L. (2003), "Assessing self-esteem", (Eds. S. J. Lopez \& C. R. Snyder), Positive psychological assessment: A handbook of models and measures, American Psychological Association: 219-233. https://doi.org/10.1037/10612-014.

Huang X., Van de Vliert E., \& Van Der Vegt, G. (2005), "Breaking the Silence Culture: Stimulation of Participation and Employee Opinion Withholding Cross-Nationally", Management and Organization Review, Vol. 1, No. 3: 459-482. doi:10.1111/j.1740-8784.2005.00023.x.

Jordan, C. H., \& Zeigler-Hill, V. (2013), "Fragile self-esteem: The perils and pitfalls of (some) high selfesteem", Current issues in social psychology. Self-esteem, (Ed. V. Zeigler-Hill), Psychology Press: 80-98.

Kalay, F., Oğrak, A., Bal, V., \& Nışancı, Z. N. (2012), "Mobbing, Örgütsel Sessizlik ve Örgütsel Sinizm iliş̧kisi: Örnek Bir Uygulama", Sakarya iktisat Dergisi, C. 3, S. 2: 1-18.

Karacaoğlu, K., \& Küçükköylü, C. (2015), "İ̧̧gören Sessizliğinin Örgütsel Sinizme Etkisi: Kamu Çalışanları Üzerine Bir Araştırma”, EgeAkademik Bakış, C. 15, S. 3: 401-408.

Kaya, N., Göncü, F. T., \& Erarslan, i. (2021), "The effects of managers' toxic leadership behaviors on organizational cynicism and employee silence (A research on the public sector)", Journal of Life Economics, Vol. 8, No. 1: 111-120. https://doi.org/10.15637/jlecon.8.1.11. 
Kernis, M. H. (2003), "Toward a Conceptualization of Optimal Self-Esteem", Psychological Inquiry, Vol. 14, No. 1: 1-26. https://doi.org/10.1207/S15327965PLI1401_01.

Lai, J. H.-W., Bond, M. H., \& Hui, N. H.-H. (2007), "The role of social axioms in predicting life satisfaction: A longitudinal study in Hong Kong", Journal of Happiness Studies: An Interdisciplinary Forum on Subjective Well-Being, Vol. 8, No. 4: 517-535. https://doi.org/10.1007/s10902-006-9029-y.

Lam, B. C. P. (2011), "How do worldviews shape self-views: An examination of the causality between cynicism and self-esteem?", Doctoral dissertation, The Hong Kong Polytechnic University.

Leary, M. R. (1999), "Making Sense of Self-Esteem", Current Directions in Psychological Science, Vol. 8, No. 1: 32-35. https://doi.org/10.1111\%2F1467-8721.00008.

Leary, M. R., Tambor, E. S., Terdal, S. K., \& Downs, D. L. (1995), "Self-esteem as an interpersonal monitor: The sociometer hypothesis", Journal of Personality and Social Psychology, Vol. 68, No. 3: 518530. https://doi.org/10.1037/0022-3514.68.3.518.

LePine, J. A., \& Dyne, L. V. (1998), "Predicting voice behavior in work groups", Journal of Applied Psychology, Vol. 83, No. 6: 853-868. https://doi.org/10.1037/0021-9010.83.6.853.

Long, C., Li, Z., \& Ning, Z. (2015), "Exploring the nonlinear relationship between challenge stressors and employee voice: The effects of leader-member exchange and organisation-based self-esteem", Personality and Individual Differences, Vol. 83: 24-30. https://doi.org/10.1016/j.paid.2015.03.043.

Longmore, M., \& Demaris, A. (1997), "Perceived Inequity and Depression in Intimate Relationships: The Moderating Effect of Self-Esteem", Social Psychology Quarterly, Vol. 60, No. 2: 172-184. https://doi.org/10.2307/2787103.

Meyerson, D. E. (1990), "Uncovering Socially Undesirable Emotions: Experiences of Ambiguity in Organizations", American Behavioral Scientist, Vol. 33, No. 3: 296-307. https://doi.org/10.1177\%2F0002764290033003004.

Milliken, F. J., Morrison, E. W., \& Hewlin, P. F. (2003), "An Exploratory Study of Employee Silence: Issues that Employees Don't Communicate Upward and Why", Journal of Management Studies, Vol. 40, No. 6: 1453-1476. https://doi.org/10.1111/1467-6486.00387.

Mirvis, P. H., \& Kanter, D. L. (1989), "Combatting cynicism in the workplace”, National Productivity Review, Vol. 8, No. 4: 377-394. https://doi.org/10.1002/npr.4040080406.

Morrison, E., \& Milliken, F. (2000), "Organizational Silence: A Barrier to Change and Development in a Pluralistic World", The Academy of Management Review, Vol. 25, No. 4: 706-725. https://doi.org/10.2307/259200.

Morsch, J., van Dijk, D., \& Kodden, B. (2020), "The Impact of Perceived Psychological Contract Breach, Abusive Supervision, and Silence on Employee Well-being", Journal of Applied Business and Economics, Vol. 22, No. 2: 1-17. https://doi.org/10.33423/jabe.v22i2.2799.

Mossholder, K. W., Bedian, A. G., \& Armenakis, A. A. (1982), "Group process-work outcome relationships: A note on the moderating effect of self-esteem", Management Journal, Vol. 25, No. 3: 575-585. https://doi.org/10.5465/256081.

Mousa, M., Abdelgaffar, H., Aboramadan, M., \& Chaouali, W. (2020), "Narcissistic Leadership, Employee Silence, and Organizational Cynicism: A Study of Physicians in Egyptian Public Hospitals", International Journal of Public Administration, 1-10. https://doi.org/10.1080/01900692.2020.1758719.

Neto, F. (2006), "Dimensions and correlates of social axioms among a Portuguese sample", Individual Differences Research, Vol. 4, No. 5: 340-351.

Nikolaou, I., Vakola, M., \& Bourantas, D. (2011), The role of silence on employees' attitudes "the day after" a merger. Personnel Review, Vol. 40, No. 6: 723741. https://doi.org/10.1108/00483481111169652.

Noelle-Neuman, E. (1991), "The Theory of Public Opinion: The Concept of the Spiral of Silence", Annals of the International Communication Association, Vol. 14, No. 1: 256-287. https://doi.org/10.1080/23808985.1991.11678790. 
Orth, U., \& Robbins, R. W. (2014), "The Development of Self-Esteem", Current Directions in Psychological Science, Vol. 23, No. 5: 381-387. https://doi.org/10.1177\%2F0963721414547414.

Pinder, C. C., \& Harlos, K. P. (2001), “Employee silence: Quiescence and acquiescence as responses to perceived injustice", Personnel and Human Resources Management, 20, Emerald Group Publishing Limited, Bingley: 331-369. https://doi.org/10.1016/S0742-7301(01)20007-3.

Pyszczynski, T., \& Kesebir, P. (2013), "An existential perspective on the need for self-esteem", Current issues in social psychology. Self-esteem, (Ed. V. Zeigler-Hill), Psychology Press: 124-144.

Rai, A., \& Agarwal, U. A. (2018), "Workplace bullying and employee silence: A moderated mediation model of psychological contract violation and workplace friendship", Personnel Review, Vol. 47, No. 1: 226-256. https://doi.org/10.1108/PR-03-2017-0071.

Roche, W. P. III. MD; Scheetz, A. P., Dane, F. C., Parish, D. C., \& O'Shea, J. T. (2003), "Medical Students' Attitudes in a PBL Curriculum", Academic Medicine, Vol. 78, No. 4: 398-402.

Rosenberg M. (1965), "Society and the Adolescent Self-Image", Princeton University Press, Princeton.

Sadeghi, M., \& Razavi, M. R. (2020), "Organizational silence, organizational commitment and creativity: The case of directors of Islamic Azad University of Khorasan Razavi", European Review of Applied Psychology, Vol. 70, No. 5, 100557:1-8. https://doi.org/10.1016/j.erap.2020.100557.

Shojaie, S., Matin, H. Z., \& Barani, G. (2011), "Analyzing the Infrastructures of Organizational Silence and Ways to Get Rid of It", Procedia- Social and Behavioral Sciences, Vol. 30: 1731-1735. https://doi.org/10.1016/j.sbspro.2011.10.334.

Smith, T. W., Pope, M. K., Sanders, J. D., Allred, K. D., \& O'Keeffe, J. L. (1988), “Cynical hostility at home and work: Psychosocial vulnerability across domains", Journal of Research in Personality, Vol. 22, No. 4: 525-548. https://psycnet.apa.org/doi/10.1016/0092-6566(88)90008-6.

Stanley, D. J., Meyer, J. P., \& Topolnytsky, L. (2005). "Employee Cynicism and Resistance to Organizational Change", Journal of Business and Psychology, Vol. 19, No. 4: 429-459. https://doi.org/10.1007/s10869-005-4518-2.

Stinson, J., Wilson, R., Gill, N., Yamada, J., \& Holt, J. (2009), “A Systematic Review of Internet-based Self-Management Interventions for Youth with Health Conditions", Journal of Pediatric Psychology, Vol. 34, No. 5: 495-510. https://doi.org/10.1093/jpepsy/jsn115.

Taşkıran, E. (2010), “Liderlik Tarzının Örgütsel Sessizlik Üzerindeki Etkisinde Örgütsel Adaletin Rolü ve Bir Araştırma", Yayımlanmış Doktora Tezi, Marmara Üniversitesi, Sosyal Bilimler Enstitüsü, İstanbul.

Trzesniewski, K., Donnellan, B., \& Robins, R. W. (2013), "Development of self-esteem", (Ed. V. Zeigler-Hill). Current issues in social psychology. Self-esteem, New York, Psychology Press: 60-79.

Vakola, M., \& Bouradas, D. (2005), "Antecedents and consequences of organisational silence: an empirical investigation", Employee Relations, Vol. 27, No. 5: 441-458. https://doi.org/10.1108/01425450510611997.

Zeigler-Hill, V. (2013), "The importance of self-esteem", In V. Zeigler-Hill (Ed.), (Ed. V. Zeigler-Hill). Current issues in social psychology. Self-esteem, New York, Psychology Press: 1-20. https://doi.org/10.4324/9780203587874.

Zhang, Y., Xu, S., Zhang, L., \& Liu, S. (2019), "How Family Support Influences Work Cynicism and Employee Silence: The Moderating Role of Gender", Cornell Hospitality Quarterly, Vol. 60, Vol. 3: 249261. doi:10.1177/1938965518788526. 


\section{Appendixes}
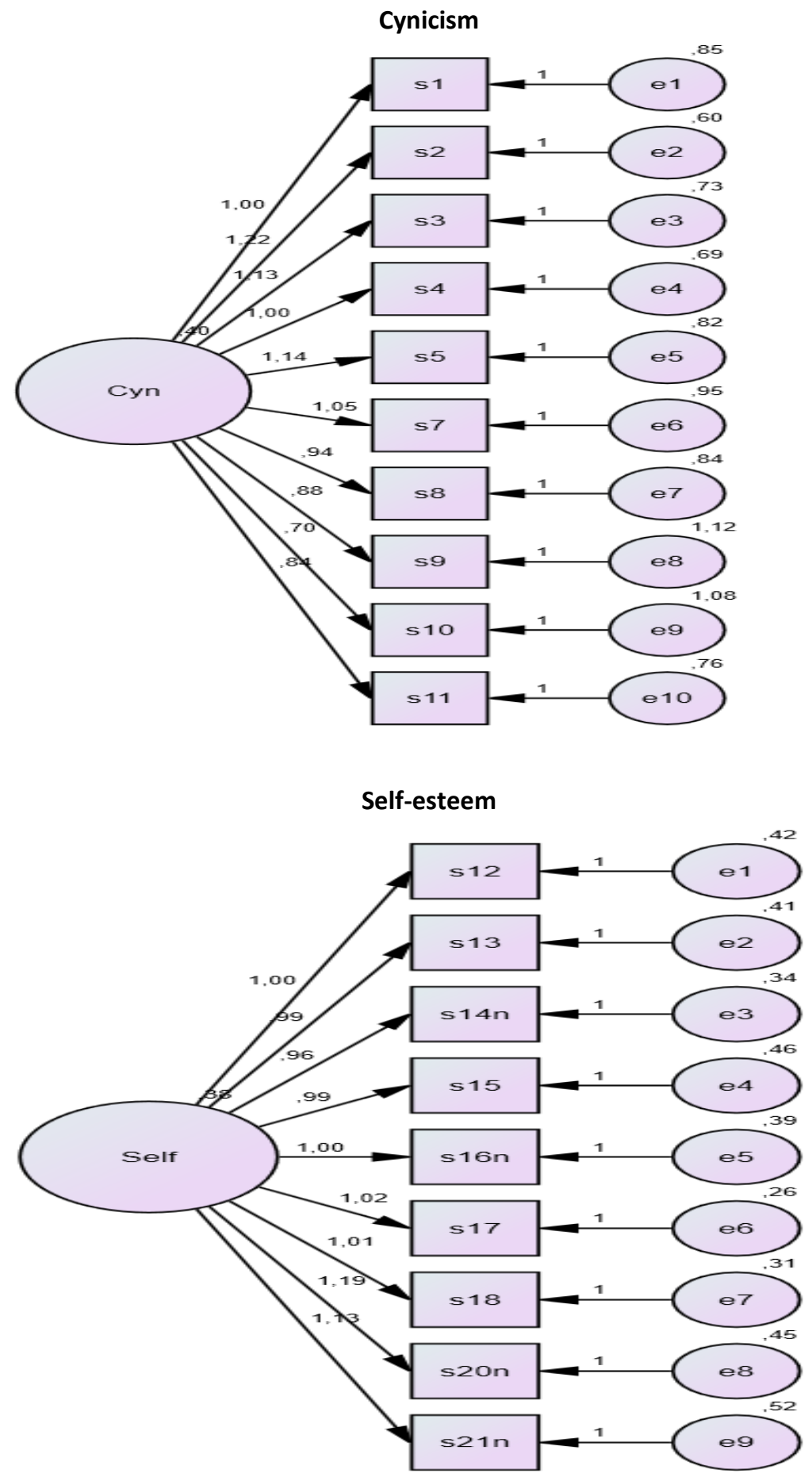


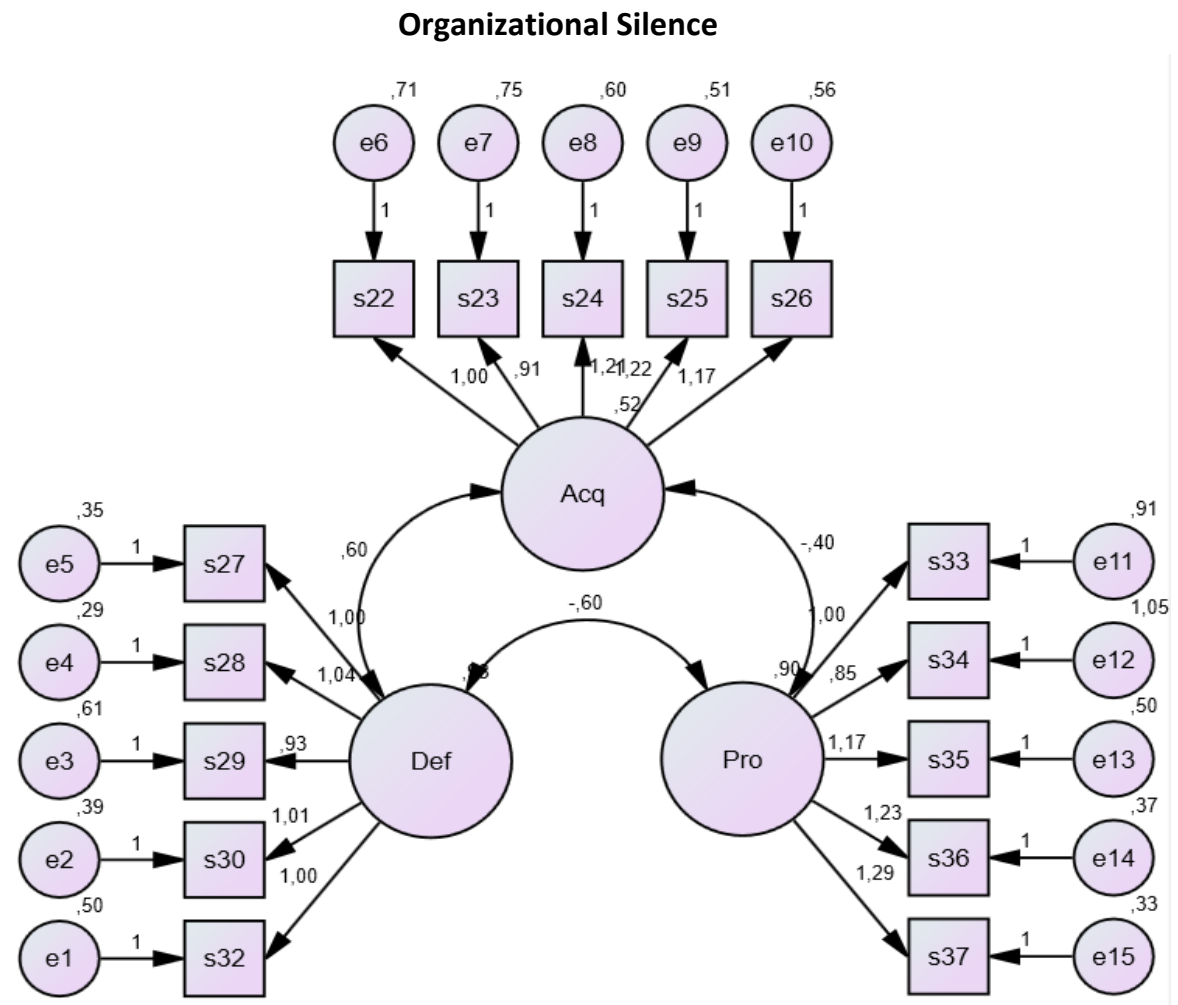


Five-factor model

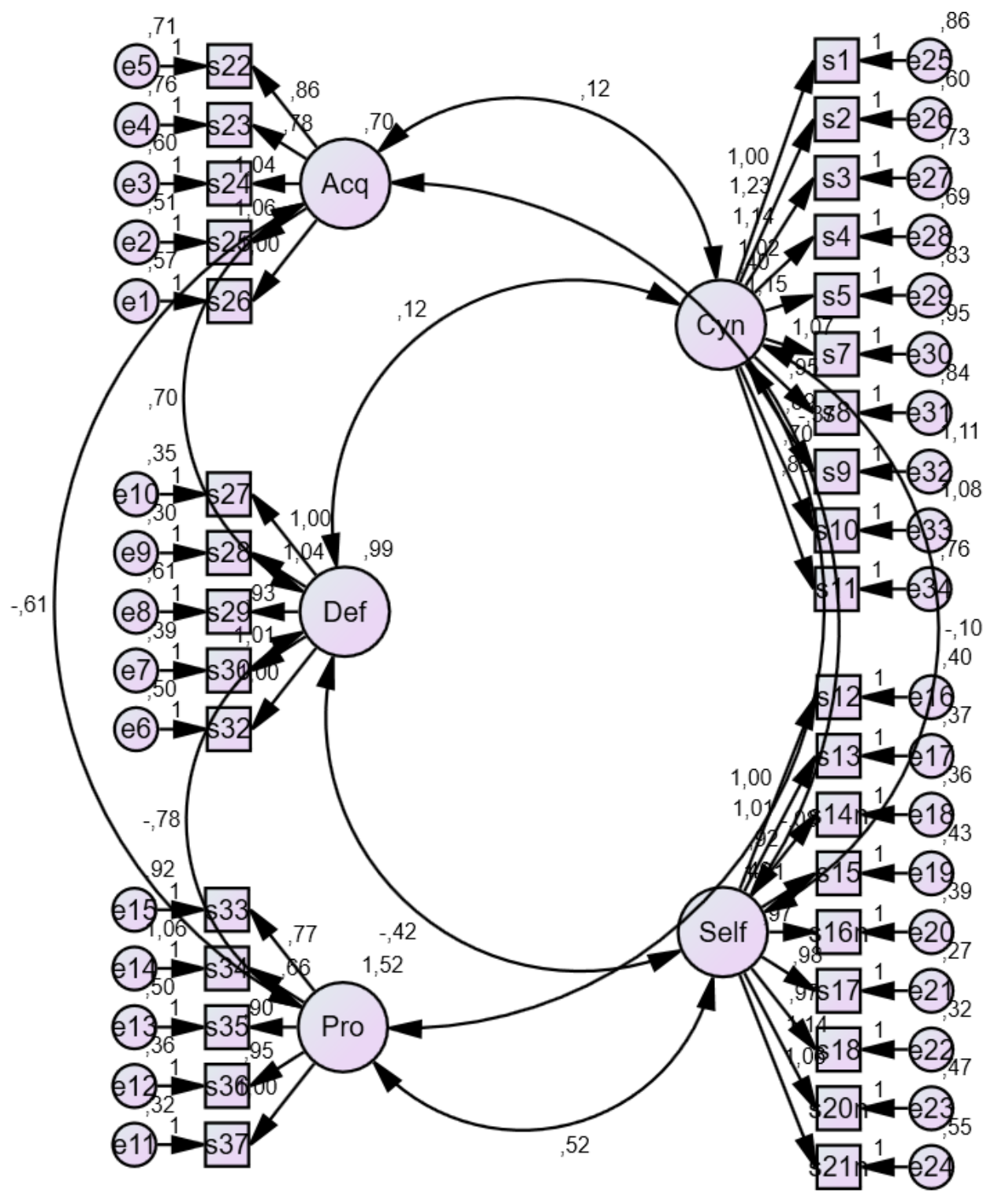

